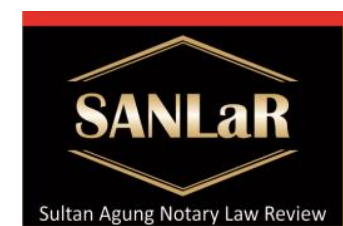

Volume 3 No. 1, March 2021

\section{Sultan Aqung Notary Law Review}

ISSN 2686-4428

published by

Master of Notarial Law

Universitas Islam Sultan Agung Semarang

The Role of Regional...( Muhammad Jaduk Chusana)

\title{
The Role of Regional Supervisory Assembly on Notary Duty
}

\author{
Muhammad Jaduk Chusana*), Gunarto ${ }^{* *}$ and Setyawati $\left.{ }^{* * *}\right)$
}

*) Student of Master of Notary Law, Faculty of Law, Universitas Islam Sultan Agung (UNISSULA) Semarang, E-mail: chusanajaduk@gmail.com

$\left.{ }^{* *}\right)$ Lecturer of Master of Notary Law, Faculty of Law, Universitas Islam Sultan Agung (UNISSULA) Semarang

${ }^{* * *}$ Lecturer of Master of Notary Law, Faculty of Law, Universitas Islam Sultan Agung (UNISSULA) Semarang

\begin{abstract}
Supervision of the Notary Profession is the authority of the Minister of Law and Human Rights. In carrying out supervision, the Minister establishes a Notary Supervisory Council which is tiered. The smallest Supervisory Council that carries out the supervisory and inspection functions is the Regional Supervisory Council (MPD). The problem is that MPD has limitations in exercising its supervisory authority and examining notaries in Sleman Regency. This research uses an empirical juridical approach, the research specifications are library research and field research. Source of data used in the form of primary data obtained by interview. Secondary Data with Literature Study. Qualitative Analysis. The problem is analyzed using the theory of authority and the theory of legal certainty. Based on the research results, it can be concluded that 1) Efforts to develop and supervise Notaries, MPD Sleman Regency are preventive activities, and include coaching activities for Notaries in their jurisdiction. 2) The implementation of supervision that must be carried out by MPD Sleman Regency has not been maximally carried out, this can be seen from: a) Supervision activities are mostly carried out around receiving reports from each Notary in Sleman Regency regarding Notary Protocol; $b$ ) MPD Sleman Regency inspection to check each Notary in their respective offices to see the office situation, this has not been maximally done because of the Covid 19 pandemic which requires examinations to be carried out online. 3) MPD Sleman Regency finds it difficult to know about violations of office.
\end{abstract}

Keywords: Notary; Notary Supervisory Council; Regional Supervisory Council.

\section{Introduction}

\subsection{Background}

The principle of rule of law guarantees certainty, order, and protection of the law which is core to truth and justice. Legal certainty, order and protection demands, among other things, that legal traffic and community life require evidence that clearly determines the rights and obligations of a person as a legal subject in society. ${ }^{1}$

\footnotetext{
${ }^{1}$ Putra Jaya, Nyoman Serikat. (2014). Politik Hukum. Semarang: Universitas Diponegoro Press. p. 117.
} 
This is also explained in Act No. 2 of 2014 regarding the amendment to Act No. 30 of 2004 concerning the Position of Notary which states that the 1945 Constitution of the Republic of Indonesia clearly determines that the Republic of Indonesia is a State of Law. $^{2}$

Legal certainty, order and protection generally require evidence that clearly determines the rights and obligations of a person as a legal subject in society. Through an authentic deed, the parties' rights, obligations and legal certainty can be clearly stated which are expected to avoid disputes. Even though according to the practice of Legal Relations there are still opportunities for disputes, with the existence of an Authentic Deed as the strongest and perfect written evidence, the juridical dispute resolution process can be resolved with legal certainty. Society needs someone whose information is reliable, trustworthy, whose signature and seal (stamp) provides Strong Guarantee and Evidence, an impartial expert and an advisor who is flawless (onkreukbaar or unimpeachable), who keeps his mouth shut, and makes an agreement who can protect him in the days to come. ${ }^{3}$

In this case the Officer in question is a Notary. This was then regulated and confirmed in Act No. 2 of 2014 on Amendments to Act No. 30 of 2004 concerning the Position of Notary (hereinafter abbreviated as UUJN). Notary is a profession that exercises some state power in the Private Law Sector and has an important role in making an Authentic Deed that has perfect evidentiary power and because the Notary Position is a Trust Position, a Notary must have good behavior.

The role of the notary in society is very important, so that supervision is needed. This supervision aims to minimize the occurrence of errors committed by notaries against the interests of clients who use their services. Habib Adjie is of the opinion that the objective of supervising a Notary when carrying out the duties of his Position must meet all the requirements related to the implementation of the duties of the Notary Public for the benefit of the people he serves. ${ }^{4}$. Another objective of supervision of a Notary is that the Notary is presented to serve the interests of the public who need Evidence in the form of an Authentic Deed according to the request concerned to the Notary Public, so that without the community who needs a Notary, the Notary is useless. ${ }^{5}$.

The supervision referred to here is supervision related to the behavior of a Notary Public and the implementation of the Notary Position in order to protect the interests of the public because Notaries are appointed by the Government not only to protect the Notary's own interests but for the interests of the public who use Notary Services.

Supervision of the Notary Profession is the authority of the Minister of Law and Human Rights, in Article 67 paragraph (1) UUJN states that Supervision of Notaries is carried out by the Minister. Article 67 paragraph (2) UUJN states that in carrying out supervision the Minister forms a Notary Supervisory Council. Article 68 UUJN states

\footnotetext{
${ }^{2}$ Law of the Republic of Indonesia Number 2 of 2014 concerning amendments to Act No. 30 of 2004 concerning the Position of Notary Public.

${ }^{3}$ Kie, Tan Thong. (2011). Serba Serbi Praktek Notaris. Jakarta: Ichtiar Baru Van Hoeve. p. 449.

${ }^{4}$ Adjie, Habib. (2011). Majelis Pengawas Notaris Sebagai Pejabat Tata Usaha Negara. Bandung: Refika Aditama. p. 3.

5 lbid, p. 3.
} 
that what is meant by the Council Monitor is the Regional Supervisory Council, the Regional Supervisory Council and the Central Supervisory Council. This Supervisory Council was formed with the intention of facilitating the performance of the Minister of Law and Human Rights as an institution that oversees the performance of Notaries.

Based on Article 1 paragraph (6) UUJN, the Notary Supervisory Council is a body that has the authority and obligation to carry out guidance and supervision of Notaries. In order to carry out the Supervisory Function carried out by the Notary Supervisory Council, Legislation has been drafted which regulates the Duties, Authorities and Obligations of the Notary Supervisory Council with UUJN. Then the Ministerial Regulation that was just officially promulgated on June 2, 2020, namely Permenkumham No. 15 of 2020 concerning the Procedure for Examination by the Notary Supervisory Council of Notaries.

In terms of the Role of the Regional Notary Supervisory Council, it has the task of carrying out examinations in the field of Notary Administration (General Legal Administration), especially in areas related to Duties and Functions as a Notary The role of the Notary Supervisory Council is vital, in terms of maintaining the dignity and nobility of the Notary Office. As well as making moral studies not only limited to regulations that look empty without any inspiration and implementation from the members.

The role of the Notary Supervisory Council here is to ensure that everything goes well in accordance with the applicable regulations, no notary person injures Marwah (Credibility) and the nobility of the Notary's Position. It is an open secret that not a few Notaries carry out their Position Functions inappropriately, such as issuing Notary Deeds of more than 20 (twenty) in 1 (one) day, engaging in brokerage practices, or even acting against the law, and a host of other problems.

\subsection{Formulation of the problem}

Based on the description of the problems above, the main problems to be studied are as follows:

1. What is the role of the Regional Supervisory Council in Notary Supervision relating to the Notary Sector (General Law Administration) in Sleman Regency?

2. What are the obstacles and solutions faced by the Sleman Regency Regional Supervisory Council in carrying out its duties and authorities?

\subsection{Research purposes}

Based on the problems formulated above, the objectives to be achieved in this study are:

1. To Assess the Role of the Regional Supervisory Council on Notary Duties in the Notary Sector in Sleman Regency.

2. To Assess the Constraints and Solutions of the Regional Supervisory Council in Supervising Notaries relating to the Notary (General Law Administration) sector in Sleman Regency.

\section{Research Methods}

The approach method used in this research is the Empirical Juridical Method. Research with the Juridical Empirical Method is research on the effect of the application of 
positive law from its legal aspects and about the effect of its effect on society. ${ }^{6}$ Basically this research is a combination of library research and field research. This specification is descriptive analysis, namely research that does not only describe the state of the object but provides an overview of the problems that occur. ${ }^{7}$

\section{Results and Discussion}

Sleman Regency is an area that has an area of $574.82 \mathrm{Km} 2$ or about $18 \%$ of the area of the Special Region of Yogyakarta. ${ }^{8}$ In addition, Sleman Regency has the highest number of Notaries in the Special Region of Yogyakarta Province, which is 180 active Notaries as of December 2020. ${ }^{9}$ This number is considered very large when compared to the total population, namely $1,180,479$ (one million one hundred eighty thousand four hundred seventy nine). ${ }^{10}$ Then the area with the second highest number of Notaries is Bantul Regency with 114 (one hundred and fourteen) Notaries, then Kulon Progo Regency with 80 (eighty) Notaries, followed by Yogyakarta City with 70 (seventy) Notaries, and finally Gunung Kidul Regency 54 (five). fourty four) Notary. The number of active Notaries in the Province of Yogyakarta Special Region is 498 (four hundred and ninety eight) Notaries. ${ }^{11}$

Based on an interview with Vanny Aldilla SH., Deputy Chairperson of the Sleman Regency Regional Supervisory Council on December 30, 2020, it was explained that the Sleman Regency MPD in carrying out its duties, the Sleman Regency MPD, to carry out its role in the framework of supervising and examining Notaries, has had a Monthly Work Program and Annual, which will be carried out during the term of office of MPD members, namely 3 (three) years from the date of appointment.

The work program of the Sleman Regency MPD is to carry out one of the duties and authorities of the Supervisory Council, namely the examination of the Notary protocol. For routine inspection purposes (once a year) as well as a certain time as needed, MPD Sleman Regency has formed an Examination Team consisting of three people from each element, assisted by one secretary.

In order to achieve an ideal supervision and inspection practice, in principle, supervision and inspection are very dependent on how the supervision and inspection are carried out. In other words, the implementation of supervision must be adjusted to the needs and objectives to be achieved through these activities. Therefore, the steps taken by the Notary Supervisory Council in carrying out the supervision and examination must be carefully thought out and carefully so that they are right on target.

\footnotetext{
${ }^{6}$ Waluyo, Bambang. (2002). Penelitian Hukum dalam Praktek. Jakarta: Sinar Grafika. p. 15.

${ }^{7}$ Soemitro, Ronny Hanitijo. (1992). Metode Penelitian Hukum dan Jurimetri. Yogyakarta: Liberty. p.27.

8 http://www.slemankab.go.id/profil-kabupaten-sleman/geografi/letak-dan-luas-wilayah diakses pada Kamis, 7 Januari 2021 pukul 18.24

9 Results of an interview with Vanny Aldilla, Deputy Chairperson of the Sleman District Notary Supervisory Council on Wednesday, December 30, 2020.

10 https://slemankab.bps.go.id/statictable/2017/11/15/253/jotal-penduduk-dan-kepadatan-pendudukmenurut-kabamatan-kota-di-di-yogyakarta-2016.html accessed on Thursday, 7 January 2021, 12.52.

11 http://siemon.kemenkumham.go.id/ accessed on Thursday, 7 January 2021, 13.00.
} 
In order to carry out the supervisory and inspection authority, MPD Sleman Regency for the first time created a Website and an Application called the Notary Monitoring Electronic Information System or commonly abbreviated as Siemon. The existence of Siemon is intended to simplify the task of the Notary Public, the duties of the MPD, as well as to make it easier for the public as part of the prospective Notary service users to obtain reliable information. According to Vanny Aldilla as deputy chairman of MPD Sleman Regency, Siemon has been running for about 2 (two) years and is considered successful in facilitating the tasks of the MPD and the notary itself. ${ }^{12}$

Talk about violations of the Notary Position or violations of the Notary Code of Ethics ${ }^{13}$, when a Notary makes mistakes related to his professionalism, the only institution authorized to examine and judge him is the Notary Professional Court, which is run by the Notary Supervisory Council in stages, this is to provide legal guarantees for the Notary profession, especially for avoid interference from any party.

There are several factors that hinder the implementation of coaching and supervision by MPD Sleman Regency towards Notaries in Sleman Regency which result in less maximal exercise of the authority of the Notary MPD in Articles 70 and 71 . These constraints are as follows:

a. As explained in the general description above, the coverage of the Sleman Regency is $18 \%$ of the Province of the Special Region of Yogyakarta. With a very large area, MPD Sleman Regency feels constrained to carry out its supervisory and inspection functions evenly.

b. Apart from its wide area coverage, Sleman Regency is listed as the Regency with the highest number of Notaries in the Special Region of Yogyakarta Province. The number of Notaries in Sleman Regency reaches 180. This huge number is then felt to be an obstacle to the MPD Sleman Regency.

c. MPD often experiences problems in making appointments to Notaries who will receive the delegation of Notary protocols.

d. Another obstacle factor is the implementation of Article 63 paragraph (5) which states that the Notary Protocol that is 25 (twenty five) years old or more is submitted by the Notary to the Regional Supervisory Council. The lack of space that the Sleman Regency Regional Supervisory Council has is also an obstacle, because the Notary deed room does not increase in size, but the Protocol will continue to increase in time.

e. The last obstacle in the implementation of supervision by the Notary MPD in Sleman Regency is due to the limited time for the members of the Notary MPD in Sleman Regency. Members are too busy in their respective jobs either as lecturers, notaries or civil servants in related agencies.

There are steps that can be taken by MPD Notary Sleman Regency to overcome obstacles in carrying out its supervisory function, namely:

a. Sleman Regency Coverage

\footnotetext{
12 Results of an interview with Vanny Aldilla, Deputy Chairperson of the Sleman District Notary Supervisory Council on Wednesday, December 30, 2020.

13 Author's explanation: In field research that occurs MPD often conducts checks for violations of the Notary Code of Ethics, which actually falls under the authority of the Notary Honorary Council (DKN).
} 
Regarding the coverage of the Sleman Regency which is very wide. Vanny Aldilla as deputy chairman of MPD Sleman Regency said that MPD Sleman Regency agreed to divide it into 3 small areas, namely the western part of Sleman Regency, the central part of Sleman Regency, and the eastern part of Sleman Regency. Then the MPD members will be further divided into 3 small groups where each group must be filled with 3 elements, namely Academics, Notaries, and Government. Each of these small groups will be assigned an assignment according to their respective small areas. ${ }^{14}$

b. Number of Notaries in Sleman Regency

As discussed above, Sleman Regency has the highest number of Notaries in Yogyakarta Province, namely 180 Notaries. The effort made by MPD Sleman Regency is to create a software in the form of a website that can be accessed via the internet network and an application that can be downloaded on a smartphone called the Notary Monitoring Electronic Information System (Siemon). Siemon can be accessed at www.siemon.kemenkumham.go.id by MPD, Notary, and the wider community. According to Vanny Aldilla as Deputy Chair of the Sleman Regency MPD, since his presence Siemon has been very helpful, especially for the Sleman Regency MPD in carrying out its supervisory and inspection functions. Vanny Aldilla also added that during the Covid 19 pandemic, almost all surveillance and inspection were carried out through Siemon. For example, in the examination, the notary is obliged to make a video regarding the things that must be reported and send the required soft file to the MPD, then MPD will communicate via video call to match the video that the notary has sent. ${ }^{15}$

c. Submission of the Notary Protocol

According to Vanny Aldilla, Deputy Chairperson of MPD Sleman Regency, it is quite difficult to determine a Notary Office in Sleman Regency that has sufficient Notary Protocol room to store the addition of Notary Protocols from other Notaries. However, in this case if it is not immediately submitted to the Notary for 30 (thirty) days, then the Protocol will be taken by MPD Sleman Regency, in accordance with Article 63 paragraph (6). ${ }^{16}$

d. Submission of the Notary Protocol who is 25 (twenty five) years old or more The obstacle for MPD in implementing 63 paragraph (5) is the limited storage space for the Notary Protocol owned by MPD Sleman Regency. The solution that can be taken so far is to move the Protocol storage space. However, the more time the Protocol increases, the space that is owned does not increase. In the future, MPD Sleman Regency wants to move to provide the Protocol in digital form, but there are still no clear rules, so MPD Sleman Regency feels that the choice of settlement is not possible. ${ }^{17}$

e. The activities of each MPD Sleman Regency members

Time management for each MPD Sleman Regency member is also an obstacle, considering that each member has their own busy schedule, both academics who have

14 Results of an interview with Vanny Aldilla, Deputy Chairperson of the Sleman District Notary Supervisory Council on Wednesday, December 30, 2020.

15 Ibid.

${ }^{16}$ Ibid.

17 Ibid. 
to teach, notaries who have to carry out their duties and positions, and civil servants. Vanny Aldilla as Deputy Chairperson of the Sleman Regency MPD said that he often encountered difficulties in setting the examination schedule. The best solution that can be done is to replace the members of the small group that the author described above. For example, a member of group 1 from the academic element is unable to attend, it will be replaced by a member from group 2 from the same element. ${ }^{18}$

\section{Closing}

\subsection{Conclusion}

The task is quite heavy for MPD Sleman Regency because this institution must be able to make maximum efforts so that the effectiveness of socialization and information to be conveyed through coaching and supervision activities in order to really achieve its goals and objectives. The existence of the Notary Supervisory Council, especially MPD Sleman Regency, is the spearhead of the Supervisory Council in the Special Region of Yogyakarta Province. The main thing is to carry out guidance and supervision of the implementation of the notary office. In providing guidance and supervision, the MPD must be responsive in handling violations committed by Notaries and must handle every violation case that occurs, so that its authority and capability is maintained in the eyes of the public. The existence of the Notary Supervisory Council should not give the impression of being an institution siding with the Notary Public. The Notary Supervisory Council must seriously become an independent institution in carrying out the guidance and supervision of Notaries.

\subsection{Suggestion}

MPD Sleman Regency must try to be more creative and careful in carrying out coaching and supervision efforts that can improve the quality and quality of service to the community, among others by:

1. Organizing regular seminars and / or training aimed at increasing the awareness of Sleman District Notaries to comply with the Regulations relating to Notary (UUJN, Permenkumham, etc.); and

2. Increasing supervision of Notaries by conducting regular and disciplined routine inspections. Sanctions against Notaries must be applied and implemented properly. As well as improving facilities and infrastructure such as increasing the storage space for Notary Protocols that are 25 (twenty five) years old or more, or switching the Notary Protocols into soft files, and being able to improve the digital facilities already owned, namely Siemon, by adding features in Reporting. Notary to MPD (Regional Supervisory Council).

${ }^{18}$ Op.Cit. 


\section{References}

Books:

[1] Putra Jaya, Nyoman Serikat. (2014). Politik Hukum. Semarang: Universitas Diponegoro Press.

[2] Kie, Tan Thong. (2011). Serba Serbi Praktek Notaris. Jakarta: Ichtiar Baru Van Hoeve.

[3] Adjie, Habib. (2011). Majelis Pengawas Notaris Sebagai Pejabat Tata Usaha Negara. Bandung: Refika Aditama.

[4] Waluyo, Bambang. (2002). Penelitian Hukum dalam Praktek. Jakarta: Sinar Grafika.

[5] Soemitro, Ronny Hanitijo. (1992). Metode Penelitian Hukum dan Jurimetri. Yogyakarta: Liberty.

Internet:

[1] http://www.slemankab.go.id/profil-kab Kabupaten-sleman/geografi/letak-danBroad-w Region accessed on Thursday, 7 January 2021 at 18:24

[2] https://slemankab.bps.go.id/statictable/2017/11/15/253/jotal-penduduk-dankepadatan-penduduk-menurut-kabamatan-kota-di-di-yogyakarta-2016.html accessed on Thursday, 7 January 2021, 12.52.

[3] http://siemon.kemenkumham.go.id/ accessed on Thursday, 7 January 2021.

Regulation:

[1] Book of Civil Law.

[2] Law of the Republic of Indonesia Number 2 of 2014 concerning amendments to Act No. 30 of 2004 concerning the Position of Notary Public.

[3] Law of the Republic of Indonesia concerning Amendments to Act No. 2 of 1986 concerning General Courts, Number 8 of 2004, TLN, No. 4379.

[4] Permenkumham Number 15 of 2020 Regarding Procedures for Examination of the Supervisory Board of Notaries

[5] Permenkumham Number M.02 / 2004 concerning Procedures for Appointing Members of the Organizational Composition, Work Procedures, and Procedures for Examination of the Notary Supervisory Council. 
Interview:

[1] Agung Wibowo, SH, M.kn. Notary in Sleman Regency, from the results of the interview on January 16, 2021.

[2] Herlina Susanti, SH Notary in Sleman Regency, from the results of the interview on January 13, 2021.

[3] Vanny Aldilla, SH Deputy Chairperson of the Sleman Regency Regional Supervisory Council, from the results of the interview on December 30, 2020. 